\title{
Comparison Quality of Life in Patient With Chronic Kidney Disease Based on Frequency of Hemodialysis in the Community: A Research During Covid-19
}

\author{
Assyfa Siti Rohmah ${ }^{1}$, Fiora Ladesvita ${ }^{1 *}$ \\ ${ }^{I}$ Nursing Program, Universitas Pembangunan Nasional Veteran, Indonesia \\ *Corresponding author. Email fiora.ladesvita@upnvj.ac.id
}

\begin{abstract}
Background: The incidence of chronic kidney disease has been increased every year. One of the treatment in these cases is hemodialysis. Hemodialysis can affect physical dan psychological that affect quality of life in patients. This study was conducted to analyze the differences in quality of life based on frequency of hemodialysis on chronic kidney patients in community. Methods: This research uses a cross sectional design and done at 66 sample with the sampling method of purposive sampling. Data collection using Kidney Disease Quality of Life Questionairre (KDQOL) versi 1.3. Results: The result using Kruskall Wallis Test showed there was a difference between quality of life based on frequency hemodialysis in the domain problem list, effects of kidney disease, patient statification, physical function, role limitation due to physical problems, general health, social function, and energy ( $\mathrm{p}$ value <0.05). Conclusion: In physics component site, patient with hemodialysis once a week has higher score of quality of life than twice weekly and thrice weekly. Whereas,in mental component site, patient with hemodialysis twice weekly has a higher quality of life score than once weekly and thrice weekly.
\end{abstract}

Keywords: Chronic Kidney Disease, Quality of Life, Frequency of Hemodialysis

\section{INTRODUCTION}

Chronic kidney disesase is condition when kidney function is decreased that occurs slowly, progressively and irreversibly [1]. The incidence of chronic kidney diseasi in Indonesia is $0,38 \%[2]$. This percentage increased by $0.18 \%$ from 2013[3]. The most common cause of CKD is Hypertension renal disease (36\%) followed by diabetic nephropathy (28\%) [4]. To minimize the complication of CKD, patients will be given therapy such as drugs, nutrition management, dialysis and kidney transplantation[5].

Based on pilot study conducted with interview the cordinator of Indonesia Kidney Care Club, nearly $90 \%$ of patient with CKD decide to undergo dialysis and $10 \%$ did not choose dialysis. The most common type of dialysis is hemodialysis.

Hemodialysis are often associated with quality of life. Quality of life (QOL) itself is the satisfaction and wellbeing by individual about their life that could affected by physical and mental health[6]. Quality of life's patient undergo hemodialysis could influenced by education, economic status, residence, frequency and duration of hemodialysis[7].
The frequency of hemodialysis for each indivial is different[8]. In Indonesia, frequncy of hemodialysis is once a week, twice weekly, thrice weekly, or more than three times a week depending on needs[4].

After doing hemodialysis, patiet ussually complain nausea, vomitting, until anorexia[5]. In addition, patients often complain of pain, sleep disturbances, and cannot work because the have to take rest[9]. That conditions can interfere quality of life.

Therefore, the aim of the research is to knowing the differences in wuality of life in patients with chronic kidney disease based on frequency of hemodialysis.

\section{METHODS}

This research using cross-sectional design, conducted in Indonesia Kidney Care Club start fom April to June 2020. Sampling was done with purposive sampling. There are 66 people with have the following criteria: patient with chronic kidney disease undergoing hemodialysis and active in the last 3 months, conscious and willing to be respondents.

Data collectiong using online form whitch consists of two parts, characteristics and quality of life. The quality 
of life questionnare used Kidney Disease Quality of Life (KDQOL) v.13 from Rand Health. Validity and reability was conducted by Shabrina \& Supadmi in 2019 with the title "Uji Validitas Kuesioner KDQOL-SF" versi Indonesia pada Pasien Penyakit Ginjal Terminal di RS PKU Muhammadiyah Bantul'"[10].

\section{RESULT}

Table 1 Average Score Quality of Life

\begin{tabular}{|c|c|c|c|c|c|c|}
\hline \multirow{2}{*}{$\begin{array}{l}\text { Quality of Life } \\
\text { Sub Domain }\end{array}$} & \multirow[t]{2}{*}{ Mean } & \multirow[t]{2}{*}{ SD } & \multirow[t]{2}{*}{ Min } & \multirow{2}{*}{$\operatorname{Max}$} & \multicolumn{2}{|c|}{ Lower $95 \% \mathrm{CI}_{\text {Upper }}$} \\
\hline & & & & & & \\
\hline $\begin{array}{l}\text { Symptoms or problems } \\
\text { perceived }\end{array}$ & 62.97 & 22.6 & 2.08 & 100 & 57.42 & 68.53 \\
\hline Effect of kidney disease & 66.20 & 23.02 & 0 & 100 & 60.53 & 71.86 \\
\hline Burden of kidnye disease & 47.40 & 23.82 & 0 & 100 & 41.39 & 53.11 \\
\hline Ability to work & 49.24 & 16.39 & 0 & 100 & 45.21 & 50 \\
\hline Cognitive function & 73.54 & 16.32 & 33.33 & 100 & 69.52 & 77.55 \\
\hline Social Interaction & 75.56 & 15.17 & 40 & 100 & 71.83 & 79.29 \\
\hline Sexual function & 83.71 & 17.40 & 50 & 100 & 79.41 & 87.99 \\
\hline Sleep quality & 65.750 & 15.94 & 30 & 100 & 61.61 & 69.45 \\
\hline Social support & 78.54 & 20.42 & 16.67 & 100 & 73.52 & 83.55 \\
\hline $\begin{array}{l}\text { Satisfaction with nurse } \\
\text { support }\end{array}$ & 76.89 & 14.58 & 25 & 100 & 73.31 & 80.48 \\
\hline General health & 71.21 & 13.30 & 40 & 90 & 67.94 & 74.48 \\
\hline Patient satisfaction & 61.36 & 20.08 & 33.33 & 100 & 56.43 & 66.78 \\
\hline Physical function & 59.85 & 24.23 & 0 & 100 & 53.89 & 65.80 \\
\hline $\begin{array}{l}\text { Limited effect by physical } \\
\text { problems }\end{array}$ & 39.02 & 35.92 & 0 & 100 & 30.18 & 47.85 \\
\hline Pain & 60.57 & 21.40 & 10 & 100 & 55.31 & 65.83 \\
\hline Perceptions of health & 51.97 & 14.36 & 20 & 80 & 48.44 & 55.50 \\
\hline Emotional well-being & 65.58 & 13.19 & 32 & 100 & 62.58 & 60.06 \\
\hline $\begin{array}{l}\text { Limited effect by emotional } \\
\text { problems }\end{array}$ & 53.54 & 36.46 & 0 & 100 & 44.57 & 62.50 \\
\hline Social function & 64.02 & 19.68 & 12.5 & 100 & 59.18 & 64.12 \\
\hline Energy/fatigue & 55.46 & 15.56 & 30 & 100 & 51.63 & 59.28 \\
\hline $\begin{array}{l}\text { Total Physical } \\
\text { Components }\end{array}$ & 38.24 & 8.4 & 19.11 & 57.25 & 36.16 & 40.31 \\
\hline Total Mental Components & 47.15 & 7.42 & 33.84 & 66.28 & 45.32 & 48.97 \\
\hline Total & 63.11 & 11.4 & 42.33 & 88.67 & 60.31 & 65.92 \\
\hline
\end{tabular}

The average score QOL patients are 63.11. Highest score is sexual function with average score 83.71 (Table 1 ). While, the lowest score is domain of limitations due to physical problems.

\section{Bivariate analysis}

There is no relationship between age, gender, dan stage of CKD with QOL in all domains ( p-value <0.05). Meanwhile, the variable of marital status affect the wuality of life in domain of cognitive function, quality of social interaction, and physical function. In addition, marital status has a relationship with general health, social functioning and energy. In educational level, only
In this research, avarage age of patients are 41 years old, male with total of 49 patients $(75.3 \%)$ and woman 17 patients $(25.8 \%)$. In marital status variable, the dominant respondents were married with number are 51 patients $(77.3 \%)$. The most recent education was higer education (diploma/ bachelor/ magister/ specialist). Most of the respodents were at stage 5 with total 61 people $(92.4 \%)$ and majority of respondents doing twice weekly hemodialysis with 39 patients $(59.1 \%)$. 
Table 4 Difference in Quality of Life Based on the Frequency Hemodialysis ( $n=66$ )

\begin{tabular}{lcccc}
\hline \multicolumn{1}{c}{ Quality of life } & \multicolumn{3}{c}{ Mean rank } \\
\cline { 2 - 4 } & $\begin{array}{c}\text { Once weekly } \\
(\mathbf{n = 1 4 )}\end{array}$ & $\begin{array}{c}\text { Twice weekly } \\
(\mathbf{n = 3 9 )}\end{array}$ & $\begin{array}{c}\text { Thrice weekly } \\
(\mathbf{n = ~ 1 3 )}\end{array}$ & P value \\
\hline Sub Domain & & & & \\
Symptoms or problems perceived & 30.25 & 39.45 & 19.15 & $\mathbf{0 . 0 0 3}$ \\
Effect of kidney disease & 40.57 & 34.99 & 21.42 & $\mathbf{0 . 0 2 6}$ \\
Burden of kidnye disease & 36.18 & 36.51 & 21.58 & 0.042 \\
Ability to work & 36.21 & 32.36 & 34 & 0.474 \\
Cognitive function & 24.14 & 35.08 & 38.85 & 0.095 \\
Social Interaction & 27.89 & 34.35 & 37 & 0.420 \\
Sexual function & 40.86 & 35.53 & 19.50 & $\mathbf{0 . 0 0 6}$ \\
Sleep quality & 33.75 & 36.92 & 22.96 & 0.075 \\
Social support & 38.79 & 33.64 & 27.38 & 0.275 \\
Satisfaction with nurse support & 28.89 & 32.59 & 41.19 & 0.110 \\
General health & 41.43 & 33.17 & 25.96 & 0.095 \\
Patient satisfaction & 20.21 & 37.12 & 36.96 & $\mathbf{0 . 0 1 0}$ \\
Physical function & 39.64 & 36.19 & 18.81 & $\mathbf{0 . 0 0 7}$ \\
Limited effect by physical problems & 36.36 & 36.86 & 20.35 & $\mathbf{0 . 0 1 8}$ \\
Pain & 29.39 & 37.91 & 24.69 & 0.063 \\
Perceptions of health & 32.50 & 38.98 & 18.19 & $\mathbf{0 . 0 0 3}$ \\
Emotional well-being & 26 & 35.59 & 35.31 & 0.254 \\
Limited effect by emotional problems & 35.43 & 35.41 & 25.69 & 0.238 \\
Social function & 38.89 & 35.96 & 20.31 & $\mathbf{0 . 0 1 7}$ \\
Energy/fatigue & 26.11 & 38.59 & 26.19 & $\mathbf{0 . 0 3 4}$ \\
\hline Total Physical Components & 36.64 & 36.51 & 21.08 & $\mathbf{0 . 0 3 4}$ \\
\hline Total Mental Components & 29.57 & 36.54 & 29.62 & 0.300 \\
\hline Total & $\mathbf{3 4 . 3 6}$ & $\mathbf{3 7 . 7 4}$ & $\mathbf{1 9 . 8 5}$ & $\mathbf{0 . 0 1 4}$ \\
\hline
\end{tabular}

\section{DISCUSSION}

\subsection{Relationship between age and $Q O L$}

Age statistically has no relationship with quality of life. The results of a study by Manavalan et al. [11] found that age did not affect the quality of life in the mental domain and components of kidney disease. In this study, both the physical and mental components had a negative relationship direction, namely $\mathrm{r}=-0.143$ and $\mathrm{r}=-0.093$. This shows that the increasing age, the quality of life decreases both physically and mentally. When viewed from the sub-domain of cognitive function and social support, it shows a different thing, namely the increasing age, the higher the quality of life score in that domain. Usually the quality of life at older ages decreases in the physical domain. Meanwhile, in the psychological, social and environmental domains, patients with more than 60 years of age have a higher qualit of life score than those less than 60 years old. This is because the young age group is not psychologically ready to accept the condition .

\subsection{Realtionship between gender and $Q O L$}

Gender has no relationship with quality of life in all domains. In line with Manavalan's research, neither the physical nor mental domains affect quality of life [11]. In this study, in almost all domains, men had lower quality of life scores than women except for physical function, cognitive function, work ability, and pain complaints. This result contradicts previous studies, where men have a higher quality of life than women in all domains [11].

In this study, social support was better on female respondents than men. Good social support will improve the patient's quality of life. This is because patients who have good social support can more easily convey complaints or problems so they can be resolved with a positive coping mechanism [14].

\subsection{Relationship between marital status with $Q O L$}

Marital status variable affects quality of life in several sub domains. Married patients also had higher QoL scores in all sub-domains than unmarried and divorced respondents. This is because individuals who are married have a partner and have a family that has the opportunity to get more intense emotional and mental support. Although emotional support is not only obtained from family. However, the research of Alexopulou et al., Proved that social support obtained from family has a better quality of life value than social support from friends or other people ( $\mathrm{p}$ value $<0.0001$, rho $=0.355)[12]$.

\subsection{Relationship between level of education with $Q o L$}

The level of education has a relationship with the mental domain component ( $p$ value $=0.027$ ). In the specific sub domain, only energy/fatigue that has a relationship with 
education level. In almost all domains, the value of quality of life has higher scores for respondents with higher education. The results of this study are in line with Kefale et al. [13], where the level of education has a relationship with quality of life and in all domains of respondents with higher education have a better quality of life score.

Some argue that higher education can make the process of receiving information about health easier so that understanding about disease is better [14]. With a good understanding, decision making in treatment becomes more effective. In addition, patients with good understanding can have more adaptive coping mechanisms [7].

\subsection{Relationship between stage of CKD with QoL}

The results of the analysis regarding the relationship between CKD stage and quality of life showed that there was no relationship between the stage of CKD and quality of life in all domains ( $\mathrm{p}$ value> 0.05). This study contradicts Manavalan et al. that found there is a relationship between the stage of CKD and quality of life in all domains [11]. At both stage 4 and stage 5, the complaints experienced by the patient were getting worse when compared to the initial stidium [5]. Although in stage 5 there will be more complaints or clinical manifestations, this quality of life is a subjective perception. So, at any stage, if the patient's perception of his life and condition is good, then the quality of life can be good. In addition, the distribution of respondents, most of whom are in stage 5 , could be a factor in the absence of a relationship between stage and quality of life.

\subsection{Differences in QoL Based on Frequency Hemodialysis}

Based on table 2, there are differences in quality of life based on the frequency of hemodialysis in the domain of symptoms or perceived problems, the effects of kidney disease, sexual function, patient satisfaction, physical function, perceptions of health, social function and energy. Table 2 also shows that the frequency of hemodialysis twice weekly has a higher quality of life value in almost all sub domains compared to hemodialysis once weekly and thrice weekly.

Patients undergoing hemodialysis has risk to experiencing nausea, vomiting, muscle cramps, headaches, and itching of the skin and anemia [5]. Anemia can cause troublesome symptoms for the patient such as fatigue and difficulty breathing [15]. One of the causes of this anemia is blood loss duringhemodialysis. Therefore, the more often a person carries out hemodialysis, the higher chance anemia will occurs. When this happens, the patient will show signs of anemia such as weakness, fatigue, pallor [5].

In addition, Rahmawati and Padoli [16] proved that as many as 20 people $(51.02 \%)$ had moderate muscle cramps, 19 people $(48.70 \%)$ had moderate itching, and 23 people $(58.90 \%)$ had moderate pain. moderate head after hemodialysis. Both of these things increase the patient's physical complaints and decrease the patient's physical function. As can be seen in Table 2, the more frequent hemodialysis is performed, the quality of life score score in the domain of physical function decreases. Although in this study, the frequency of hemodialysis had no relationship with quality of life in the social domain. However, from the average score, the results showed that respondents with a frequency of hemodialysis once weekly had a higher score than twice weekly. The large number of hemodialysis performed makes it difficult for a person to interact with other people [17].

By decreasing social interaction, it is possible that the social support received by respondents will decrease. When this happens, the individual can feel a loss of security and a sense of belonging or feeling loved [18]. If this continues, it can certainly increase the patient's stress level. A study by Rahayu et al. [19] showed that the frequency of hemodialysis had a relationship with stress levels $(\mathrm{p}$ - value $=0.041)$, where the more often the subject performed hemodialysis, the heavier the stress level in the patient. When a person experiences stress, he will usually experience complaints such as loss of appetite, weight loss, lack of energy, headaches, indigestion, and sleep disorders [18]. So that not only the physical function is disturbed, but also psychologically.

\section{CONCLUSIONS}

There is a difference between the frequency of hemodialysis performed and the respondent's quality of life in the domain of symptoms or perceived problems, sexual function, effects of kidney disease, patient satisfaction, physical function, limitations due to physical problems, general health perceptions, social function and energy or fatigue ( $\mathrm{p}$ value $<0.05$ ). In the total physical domain component, the results obtained a higher score on the frequency of hemodialysis once weekly compared to twice weekly and thrice weekly. Whereas in the mental component domain, the frequency of hemodialysis twice weekly had a higher quality of life score than once weekly and thrice weekly.

\section{REFERENCES}

[1] White L, Duncan G, Baumle W. Medical-Surgical Nursing: An Integrated Approach. 3 Ed. Clifton Park, Newyork: DELMAR CENGAGE Learning; 2013.

[2] Kementerian Kesehatan RI Badan Penelitian Dan Pengembangan. Hasil Utama Riset Kesehatan Dasar [Internet]. Kementrian Kesehatan Republik Indonesia. Kementerian Kesehatan Republik Indonesia; 2018. 43 Hal. Tersedia Pada:

Http://www.Depkes.Go.Id/Resources/Download/InfoTerkini/Hasil-Riskesdas-2018.Pdf

[3] Kementerian Kesehatan Republik Indonesia. Hasil Utama Riset Kesehatan Dasar (RISKESDAS) 2013 2013.

[4] Indonesian Renal Regisrty (IRR). 11 Th Report Of Indonesian Renal Registry 2018. 2018.

[5] Black JM, Hawks JH. Keperawatan Medikal 
Bedah: Manajemen Klinis Untuk Hasil Yang Diharapkan. 8 Ed. Singapore: ELSEVIER; 2014.

[6] Rustandi H, Tranado H, Pransasti T. Faktor-Faktor Yang Mempengaruhi Kualitas Hidup Pasien Chronic Kidney Disease (Ckd) Yang Menjalani Hemodialisa. J Keperawatan Silampari. 2018;1(2).

[7] Ashok A, Sharma K, Ra AA, Parihar NB, Sajith M, Jawale S, Et Al. Factors Affecting Quality Of Life In Heamodialysis Patients In Tertiary Care Hospital. Biomed Pharm Sci. 2019;2(1):1-6.

[8] Lemone P, Burke KM, Bauldoff G. Buku Ajar Keperawatan Medikal Bedah - Gangguan Eleminasi. 5 Ed. Jakarta: EGC; 2016.

[9] Ipo A, Aryani T, Suri M. Hubungan Jenis Kelamin Dan Frekuensi Hemodialisa Dengan Kualitas Hidup Pasien Gagal Ginjal Kronik Yang Menjalani Hemodialisa Di Rumah Sakit Umum Daerah Raden Mattaher Jambi. J Akad Baiturrahim. 2016;5(2).

[10] Shabrina AN, Supadmi W. Uji Validitas Kuesioner KDQOL-SFTM Versi Indonesia Pada Pasien Penyakit Ginjal Terminal Di RS PKU Muhammadiyah Bantul. AKFARINDO. 2019;4(2).

[11] Manavalan M, Majumdar A, Harichandra Kumar KT, Priyamvada PS. Assessment Of Health-Related Quality Of Life And Its Determinants In Patients With Chronic Kidney Disease. Indian J Nephrol [Internet]. 2017;27(1):37-43. Tersedia Pada:

Http://Www.Indianjnephrol.Org/Article.Asp?Issn=097 1 -

4065; Year $=2017 ;$ Volume $=27 ;$ Issue $=1 ;$ Spage $=37 ;$ Epage $=43 ;$ Aulast $=$ Manavalan

[12] Alexopoulou M, Giannakopoulou N, Komna E, Alikari V, Toulia G, Polikandrioti M. The Effect Of Perceived Social Support On Hemodialysis Patients' Quality Of Life. Mater Sociomed. 2016;28(5):338-42.

[13] Kefale B, Alebachew M, Tadesse Y, Engidawork E. Quality Of Life And Its Predictors Among Patients With Chronic Kidney Disease : A Hospital-Based Cross Sectional Study. Plos One. 2019;14(2).

[14] Uddin MA, Soivong P, Lasuka D, Juntasopeepun P. Factors Related To Quality Of Life Among Older Adults In Bangladesh: A Cross Sectional Survey. Nurs Heal Sci. 2017;

[15] Fishbane S, Ross DW, Hong S. Anemia In NonDialysis-Dependent CKD: To Treat Or Not To Treat? Am J Kidney Dis [Internet]. 2019;73(3):297-9.

Tersedia Pada:

Https://Doi.Org/10.1053/J.Ajkd.2018.11.006

[16] Rahmawati BA, Padoli. Kejadian Komplikasi Intradialisis Klien Gagal Ginjal Kronik Di Ruang Instalasi Hemodialisis RSUD Dr.M. Soewandhie Surabaya. J Keperawatan. 2017;X(1).
[17] Imelda F, Susalit E, Marbun MBM, Rumende CM. Gambaran Klinis Dan Kualitas Hidup Pasien Penyakit Ginjal Tahap Akhir Yang Menjalani Hemodialisis Dua Kali Dibandingkan Tiga Kali Seminggu. J Penyakit Dalam Indones. 2017;4(3).

[18] Videbeck SL. Psychiatric-Mental Health Nursing. 5 Ed. Philadelphia: Wolters Kluwer Health/ Lippincott Williams \& Wilkins; 2011.

[19] Rahayu F, Ramlis R, Fernando T. Hubungan Frekuensi Hemodialisa Dengan Tingkat Stress Pada Pasien Gagal Ginjal Kronik Yang Menjalani Hemodialisis. J Keperawatan Silampari. 2018;1(2). 